\title{
Drivers of SMEs' exporting activity: a review and a research agenda
}

Article

Accepted Version

Francioni, B., Pagano, A. and Castellani, D. (2016) Drivers of SMEs' exporting activity: a review and a research agenda. Multinational Business Review, 24 (3). pp. 194-215. ISSN 1525-383X doi: https://doi.org/10.1108/MBR-06-2016-0023 Available at https://centaur.reading.ac.uk/66857/

It is advisable to refer to the publisher's version if you intend to cite from the work. See Guidance on citing.

Published version at: http://www.emeraldinsight.com/doi/full/10.1108/MBR-06-2016-0023

To link to this article DOI: http://dx.doi.org/10.1108/MBR-06-2016-0023

Publisher: Emerald Group Publishing Limited

All outputs in CentAUR are protected by Intellectual Property Rights law, including copyright law. Copyright and IPR is retained by the creators or other copyright holders. Terms and conditions for use of this material are defined in the End User Agreement.

\section{www.reading.ac.uk/centaur}

\section{CentAUR}

Central Archive at the University of Reading

Reading's research outputs online 


\section{Drivers of SMEs' exporting activity: a review and a research agenda}

\section{Introduction}

Small and medium enterprises (SMEs) are the backbone of the economy of the European Union (EU) and the long-run competitiveness of the EU critically depends on the ability of SMEs to be active in international markets (European Commission, 2014).

Over the past decades, the exporting activities of SMEs have been extensively analysed in international business studies. Various contributions have explored barriers and stimuli for exporting activities (Leonidou, 2004; Leonidou et al., 2007), as well as the main determinants, the underlying processes and the effects on performance of firms' decisions to set up international activities (Jones and Coviello, 2005; Pangarkar, 2008).

However, there is a lack of comprehensive and systematic reviews of contributions on the drivers of SME internationalisation during the last decade. Recent literature reviews concern restricted, although important, set of drivers of exporting activities, such as innovation and performance (Love and Roper, 2015). The last comprehensive review of the literature and interpretative framework on the drivers of SMEs exporting has been published by Leonidou $e t$ al. (2007). While their classification scheme has provided a clear and widely accepted frame to investigate a variety of stimuli, the complexity of internationalisation processes undertaken by firms has increased in the last decade, and in the aftermath of the global economic crisis in particular. Thus, a systematic and updated assessment of more recent studies on SMEs' exporting stimuli is highly needed, in order to understand whether academic research has unveiled emerging relevant factors shaping the exporting behaviour by SMEs while facing the recent dramatic changes in the world economy.

Therefore this article aims to contribute to this growing academic debate on SMEs' internationalization processes providing a systematic review of recent empirical articles on key exporting stimuli for SMEs, through a classification framework based on the scheme proposed by Leonidou et al. (2007), with the integration of emerging drivers, as highlighted in recent empirical studies.

The remainder of the paper is structured in four sections. The next section outlines the methodology adopted for this review. Then the third section shows the main findings of the literature review, which is based on internal and external drivers of exporting activities. The fourth and final section analyses the main results and then outlines future research paths and main policy-making implications. 


\section{Methodology}

In order to develop a comprehensive and systematic review, we followed an approach similar to the one proposed by Tranfield, Denyer, and Smart (2003) and adopted in other international and small business literature reviews (Kontinen and Ojala, 2010; Ojala and Isomäki, 2011). Therefore, we divided the review process into three main steps: 1) planning the review; 2) conducting the review; 3 ) reporting.

Firstly, we carried out a computerized search through different and important electronic databases, such as EBSCO (Lauf and Schwens, 2014) Emerald, ScienceDirect, JSTOR, Springer, and Wiley/Blackwell (Ojala and Isomäki, 2011), using some specific and selected keywords: small business, small enterprises, small firms, SMEs, internationalization, internationalization, export, exporting, exports, exporters, driver, stimulus. We exclude books and book sections, masters and doctoral theses, conference papers, unpublished working papers and also publications that are non-peer reviewed and not in English. In addition, we focus our review on articles published between 2006 and 2015. We select 2006 as a starting point as this study builds on Leonidou et al. (2007), which examined papers published until 2005. Moreover, a decade is the reference period adopted in previous SMEs-related literature reviews (Gorman et al., 1997; Tracey, 2014), which is long enough to allow identifying evolutionary trends, patterns, and themes in the field.

Regarding the second step, each article was examined and classified into drivers building on classification previously identified by Leonidou et al. (2007), which provide and discuss an integrated and exhaustive synthesis of export stimuli in SMEs. In their view, this effort would have further promoted new avenues of research on a consolidated topic. Leonidou et al. (2007) argue that the firm's engagement in exporting activities is the result of an array of internal and external stimuli. The former are associated with factors endogenous to the firm, such as the accumulation of unsold inventory, the desire for corporate growth, the possession of a unique product, while external stimuli are derived from the environment within which the firm operates or intends to operate, such as the unsolicited orders from abroad, favourable exchange rates, encouragement by government agencies. The review of the literature carried out by Leonidou et al. (2007) revealed 52 export stimuli, which were further refined and merged into 40 export stimuli, and finally grouped into 13 categories which are illustrated in detail in Table I. In short, internal stimuli can be classified according to the firm's main business functions, such as human resources, marketing, production, research \& development (R\&D), while external stimuli instead are linked to the home and host markets and governments, to customers, intermediaries and competition level. Leonidou et al. (2007) conclude that each 
stimulus may have a different frequency, intensity, or importance, according with time, spatial, and industry contexts. However, irrespective of contextual factors, they also reveal that motives such as the desire to achieve extra sales, profits, and growth, to exploit a unique/patented product, to reduce home market dependence, and to respond to unsolicited orders from abroad, systematically play a key role in encouraging small firms to export. Other important stimuli include: special managerial interest in exports, avoidance of the threat of a saturated domestic market, utilisation of better idle production capacity, possession of a financial advantage, need to achieve economies of scale, need to exploit proprietary technical knowledge, and identification of better opportunities abroad.

While in this paper we largely build on Leonidou et al. (2007), in order to be able to make an assessment on the direction of evolution of research, we also create a new category of drivers, we rename some categories and group together other categories. With regard to internal drivers, we operate three changes. Firstly, we introduce the category "R\&D, innovation and productivity" which groups together contributions dealing with innovation both in terms of product and process innovation. Moreover, innovation and productivity are two related factors which have a significant effect on exporting performance. Secondly, we rename the "Marketing" category as "Marketing/Sales" in order to highlight the different role that marketing and sales - as market-focused functions - might play, particularly in SMEs where often marketing is a neglected and unstructured business activity. Thirdly, we explicitly introduce Purchasing as a distinct category because internationalization processes are increasingly related also to international sourcing activities, which might provide new opportunities for market growth through exports. With regard to external drivers, we introduced two new categories ("home-country" and "host-country") including both market and government drivers, in order to simplify the structure of the framework while maintaining the sub-categories. Then we introduce the new category "network", which includes some of the categories (intermediaries, customers) proposed by Leonidou et al., (2007) among external drivers. This choice is due to two main reasons. Firstly, export stimuli might be provided by a wide range of business and institutional actors; secondly, the development of bilateral relationships is increasingly analyzed in combination with concurrent and interdependent relationships, leading to a network configuration. This allows us to highlight new and emerging drivers of SMEs' exporting activities, which then provide us with insights to update Leonidou's classification scheme, and to identify future research directions. This taxonomy allows us to focus our review and to exclude articles which are not analysing one or more specific factors. 
All in all, after excluding also conceptual papers and literature reviews, we are left with a total of 69 papers.

The third step will be developed in the next section, where we report the findings of our analysis, and identify the most studies topics, highlighting both established and key emerging themes.

$$
* * * \text { Table I*** }
$$

\section{Drivers of SMEs exporting activity: a review of empirical studies from 2006 until 2015}

\section{Internal drivers}

\section{a) Human resources}

Various studies emphasize the role of human resources (HR) involved in SMEs' internationalization processes. The characteristics of human capital affect the ability of SMEs to undertake expansion projects in foreign markets: based on a dataset of Belgian SMEs, Onkelinx et al. (2015) show that there is a strong relationship between investments in human capital and the firm's export intensity, when SMEs follow a strategy of accelerated internationalization. Cerrato and Piva (2012), through an empirical investigation of a sample of 1,324 Italian SMEs aimed at detecting the main factors affecting expansion in foreign markets, indicate that the level of human capital has a positive impact on the internationalization process.

Specifically, recent contributions place emphasis on three distinct categories of factors stimulating exporting activities in SMEs: competences, cognitive-related factors, sociodemographic-related factors.

Many reviewed contributions highlight the impact of specific competences, experiences and knowledge related to exporting activities and foreign markets. Fernandez-Ortiz and Lombardo (2009) carry out a survey on 219 Spanish SMEs, providing evidence that the international diversification of SMEs is positively related to both the level of international experience and managers' foreign language proficiency. Another Spanish survey conducted by Belso-Martınez (2006a) examines the profile of international manufacturing SMEs: findings confirm that there is a connection between internationally experienced managers and rapid internationalisation processes (Fernandez-Ortiz and Lombardo, 2009). A quantitative study conducted by Zucchella et al. (2007) on 144 Italian SMEs shows that entrepreneurial factors, and in particular the previous international experience, are relevant drivers for early internationalization. Musteen et al. (2010) investigate a possible relationship between CEOs' international relationships and the speed with which their firms internationalise. In their 
empirical analysis of 155 Czech SMEs they find that "linguistic congruency between SME CEOs and their international ties facilitates faster internationalization" (Musteen et al., 2010; p. 203). In line with these findings, some contributions highlight the positive role of educational levels (Serra et al., 2012; Hsu et al., 2013).

Many articles underline the effect of a wide variety of cognitive-related factors, thus showing the complexity of this specific subject. These contributions focus on personality/subjective characteristics, such as risk attitude, perception of costs, perception of benefits, commitment, overall approach, global mindset. Lamb et al. (2011) develop a qualitative study, focused on Australian small wineries, and their findings reveal that differences in owner-manager internationalisation practices derived from their understandings of internationalisation, which in turn lead to variation in organization activities within their internationalisation activity cycle. Omri and Becuwe (2014, p. 31) carry out an empirical study on Tunisian SMEs. Results reveal that "personality traits positively enhance innovative behavior of managers seeking to internationalize their products and services". Miocevic and Crnjak-Karanovic (2011), after conducting a study on 125 Croatian exporting SMEs, show a relationship between information and cognitive-based capabilities on international performance. Pangarkar and Hussain (2013) undertake a study of Singaporean SMEs, and their results demonstrate a strong connection between international orientation of managers and degree of internationalization. Serra et al. (2012) examine export propensity in the textile and clothing sector for $165 \mathrm{UK}$ SME, highlighting that perception of costs is an important factor. Acedo and Galan (2011) through an empirical study of small firms in Spain, find that two main variables, namely the decision-maker's proactiveness and perception of risks and opportunities in exports, have a high level of influence on export stimuli and consequently on international behaviour. Kaur and Singh (2013) adopted a multiple-case-study method for examining the internationalization of Malaysian born global firms. Results revealed that one of the main factor leading early internationalization is the entrepreneurial orientation of founders/managers. Lastly, Williams (2008), in a study on Jamaican small firms, shows that export initiation is mainly the result of a planned systematic effort to international markets rather than a reactive approach to market developments.

Several reviewed studies focused on the global mindset, that has been defined by Kyvik et al. (2013, p.174) "as a determinant for CEOs' strategic perception of the global market". The same authors, using samples of small Norwegian and Portuguese firms, find a strong causal relationship between the global mindset and SMEs' internationalisation behavior. Similar results were also found in two other studies carried out by Felicio et al. (2012; 2015). 
A number of contributions place emphasis on socio-demographic factors related to the origin of shareholders/entrepreneurs/owners in charge of leading SMEs' presence in export markets. Cerrato and Piva (2012), based on a survey of Italian SMEs, find that there is a positive relationship between the presence of foreign shareholders and SMEs' internationalization. Through a research on a sample of 3,077 Canadian SMEs, Sui et al. (2015) find that SMEs owned by immigrants have a higher propensity to internationalize.

Other studies examine the role of family ownership, although results are controversial. Fernandez and Nieto (2006), using a sample of Spanish SMEs, find that family ownership negatively affect SMEs' exporting activity. On the contrary, Chen et al. (2014) find a positive relationship. Finally, Sciascia et al. (2012), based on a sample of U.S. family SMEs, find a nonlinear relationship.

Some studies focus on the impact of manager and owner's age and gender on the ability to compete in foreign markets. Serra et al. (2012) analyse 165 UK SMEs, and find that firms with younger managers exhibit a higher propensity to internationalize. Another study by Orsen et al. (2010) highlights the role of gender. Findings derived from a survey of Canadian SMEs indicate that female-owned firms were significantly less likely to export than firms owned by men.

Another factor highlighted in the reviewed articles concerns HR management measures, even though indirectly, and still to a limited extent. Analysing exporting SMEs from Cyprus, Coudounaris (2011) finds that managers' financial and non-financial rewards influence their level of morale, which in turn affects their behavioural and outcome performance, and ultimately affects firms' export propensity.

\section{b) Research \& Development, innovation activities and productivity}

A number of reviewed contributions focus on R\&D and innovation as drivers of internationalization of SMEs, but results are not univocal.

Using data on Spanish SMEs, Cassiman et al. (2010) identify product innovation, but not process innovation, as a driver of firm-level export propensity. D'Angelo (2012), analysing the relationship between innovation and export performance of 689 Italian high-technology SMEs, finds that export intensity is positively associated with the number of workers employed in $R \& D$ activities, the use of universities as external $R \& D$ partners, product innovations and the turnover derived from innovative activities; however, he also shows that R\&D expenditures have no influence on export intensity. On the other hand, Damijan et al. (2010), using data on the Slovenian manufacturing sector and applying matching techniques to account for the 
endogeneity of the innovation activities, find no evidence that product or process innovation acts as a significant driver of export propensity at the firm level. This holds true for both smalland medium-sized firms defined with 50 to 200 employees. In a sample of 945 Spanish SMEs Ramos et al. (2011) do not find a positive correlation between the firms' decision to invest in patents and utility models and the rapid access to international market.

Related to innovation, also productivity is considered as one of the main dimensions of performance affecting internationalisation. For example, in the case of Sweden, Falk and Hagster (2015) carry out a research based on uniquely linked firm-level datasets with full coverage of micro enterprises in the computer and business service industries. Results reveal a positive relationship between initial labour productivity and the decision to export. Similarly, Eliasson et al. (2012) find that there is higher productivity among future Swedish exporters in comparison with non-entrants before they start internationalization activity. However, Cassiman and Golovko (2011), using a panel of Spanish manufacturing SME, show that the positive association found between firm productivity and exports relates to the firm's earlier innovation decisions, and that, when controlling for product innovation, the relationship between productivity and exports vanishes.

\section{c) Marketing}

The role of marketing-related factors is addressed mainly by looking at aspects such as the availability of marketing capabilities, and notably the adoption of ICT/web technologies for access and interaction in foreign markets.

With regard to marketing capabilities, Rundh (2007) investigates the main export drivers affecting Swedish manufacturing firms, attempting to discover possible differences between small and large firms. Results reveal that there is not a general difference among small and large firms and factors such as the possession of a marketing competitive advantage, longterm possibilities for growth and profit and management's interest in exporting are important in stimulating initial engagement. Based on data collected from 283 Spanish manufacturing SMEs, Belso-Martinez (2006b) finds that marketing differentiation, in combination with other factors, has a strong impact on export performance. Similarly, Frishammar and Andersson (2009) find that, in a sample of 188 Swedish SMEs, market orientation has a positive influence on international performance.

It is worth noting that a significant number of recent contributions focus on the role of internet/web on SMEs' exporting activities. Tseng and Johnsen (2011), through multiple case studies of ten UK manufacturing SMEs from several UK sectors, analyse the impact of the 
internet on the internationalisation process, and results demonstrate that the level of technological advancement of a SME has a strong impact on the adoption of internet for supporting the internationalization process and international customer communications and interactions. Bell (2010) presents five case studies and illustrates how these SMEs adopt Web 2.0 tools and techniques to reinforce and enhance their internal and external capabilities, leading to early internationalization. Loane (2006) investigates the role played by the Internet in the internationalisation on a cross-national sample of 53 small entrepreneurial firms from Canada, Ireland, Australia and New Zealand. Main results reveal that in the majority of cases SMEs attempt to use internet for supporting the firms' strategic international growth objectives, such as the coordination of complicated value chain activities. Sinkovics et al. (2013), collecting information and data from 115 UK-based SMEs involved in active online internationalisation, go through a more in-depth analysis of the drivers and performance of two typology of internet use to support export marketing: the internet as an alternative or a substitute to a physical market presence and the internet as a sales channel. Findings show that, while there is a positive relationship between online channel support and export performance, there is no relationship between the adoption of the internet as an alternative to a physical presence and export performance. Entrepreneurial firms that adopt the internet as a sales channel, however, can enhance their overall performance. Mostafa et al. (2006) investigate the relationship between entrepreneurial orientation, commitment to the Internet and export performance in $158 \mathrm{UK}$ SMEs. Their empirical evidence shows that SMEs with high entrepreneurial orientation are significantly more likely to be more committed to the Internet and to have higher international performance.

\section{d) Purchasing}

A few studies highlight that previous purchasing activities by SMEs could represent a relevant driver for export orientation. Holmlund et al. (2007) undertake a survey of Finnish SMEs and results from the empirical analysis show that importing-experience has influence on exporting. In another contribution, Ottaviano and Volpe Martincus (2011) investigate a sample of SMEs based in Argentina and discover that sourcing from abroad is associated with higher probability of exporting.

\section{External drivers}

a) Home country factors 
The characteristics of the home market, as well as the policies of the home government have been examined in a number of reviewed contributions.

With regard to the role of the home market, Rodriguez (2007) undertakes a research of 550 SMEs located in Finland, Mexico, Australia, the UK and France aiming to examine differences and similarities in internationalisation strategies. Findings reveal that a declining domestic market contributes to explain the probability to export, although it represents only a secondary driver. Similarly, Rundh (2007) discovers that for Swedish SMEs the second most important driver is the stagnation of the domestic market. It is interesting to note that in both studies the saturation/shrinkage of the domestic market is considered as an important motive, but not the most important. Karadeniz and Göçer (2007), after conducting a study on a sample of 471 Turkish SMEs, find a negative relationship between the growth rate of the domestic market and the SME's internationalization.

As concerns the role of the domestic government, various studies focus on policies related to export promotion programs (EPP), which represent the key set of measures used by home governments to support SMEs in improving their export performance. Wilkinson and Brouthers (2006), based on a survey of 105 US SMEs, find that US-states support in trade fairs participation, and in identifying agents and distributors, had a positive effect on SMEs satisfaction with export performance. Durmuşoğlu et al. (2012) conduct a survey of 143 SMEs in Turkey showing that EPP support measures helped firms in achieving a variety of objectives, namely financial, stakeholder relationship, strategic and organisational goals. Sousa and Bradley (2009) carry out a confirmatory factor analysis and structural equation modelling on 287 Portuguese SMEs and find support for their hypothesis that export assistance programmes and distributor support are significant determinants of export performance. Moreover, Bonner and McGuinness (2007), based on data from 324 Northern Ireland SMEs, find that "marketing assistance is particularly beneficial when targeted towards smaller SMEs and those who are already active in export markets" (Bonner and McGuinness, 2007, p.377).

With respect to the role and effects of export credits and guarantees, only a few studies focus specifically on SMEs. After gathering data from four Chinese province, Cardoza et al. (2015) find that Chinese SMEs with financial support from the government are more likely to expand internationally.

\section{b) Host country factors}


SMEs' exporting activities and performance might be influenced by host country factors. Recent contributions concern mainly foreign market related factors, while the role of host government is not analysed.

According to a survey conducted by Crick (2007b) on 448 UK SMEs, the "potential for extra growth from serving overseas markets" is the most important motive for SMEs that decided to concentrate on key overseas markets. Garvey and Brennan (2006) complete a study of 279 indigenous Irish software technology companies finding that firms' exporting decisions are primarily motivated by market growth.

A number of studies point out the role of the identification of better opportunities abroad. Torkkeli et al. (2012), through a survey of from 298 Finnish SMEs in metal, food, furniture, software and knowledge-intensive business services, find that lower levels of environmental hostility have positive links to SMEs' export propensity. Nowinski and Rialp (2013), applying a multiple case study methodology on Polish new ventures, observe that opportunities for foreign market arbitrage are an important stimulus for early internationalisation.

A few contributions address also the dimension of proximity between country of origin and host market. In their comparative study, Korsakienè and Tvaronavičienė (2012) find that proximity to customers and suppliers, small domestic market and competitive pressure are the most powerful factors affecting internationalisation of both Lithuanian and Norwegian SMEs. However, only Lithuanian SMEs distinguish the most important criteria for international market selection as geographic proximity.

\section{c) Networks}

In the last three decades a network-based approach has emerged to describe and explain the international behaviour of firms (Coviello and Munro, 1997; Johanson and Vahlne, 2009). These theoretical advancements have been used to explore the process of entry and expansion of SMEs in foreign markets more in detail.

A few studies focus mainly on personal networks, based on social interaction. Xie and Amine (2009) investigate how Chinese managers take decisions during internationalization. Results reveal that the possibility to get information about foreign countries through social networks is considered as one of the most important stimulus to internationalisation. Through a quantitative research on a sample of 169 Czech SMEs, Musteen et al. (2014) show that chief executive officers with established and varied international networks had greater comprehension and knowledge of foreign markets before internationalization. In the case of 
family SMEs, it has been shown that existing social ties have been less effective in approaching new foreign markets (Kontinen and Ojala, 2011).

Most of the contributions examine networks at the inter-organizational level. A few studies emphasize the role of local networks. Based on empirical data collected from 283 Spanish manufacturing SMEs, Belso-Martinez (2006b) investigates the relationship between the location inside industrial districts and both export performance and intensity. His empirical findings reveal that industrial district location, in combination with other factors, have a strong impact on export performance. Many other contributions highlight the role of international ties. Ciravegna et al. (2014) carry out a comparative research on 58 high technology small firms located in Italy and Costa Rica for understanding how they create, develop and use networks to start internationalization. Results reveal that, through the adoption of specific strategies, the majority of SMEs from both countries create and use networks for supporting their internationalization activities. With the aim to discover the role of vertical and horizontal cooperation through a survey of SMEs from Argentina, Mesquita and Lazzarini (2008) show that such collaboration allows for enhanced productivity and innovation, which then help SMEs to expand in foreign markets.

Relationship and networks play a pivotal role notably when SMEs undertake international expansion projects in countries with higher social and institutional variety, such as emerging markets (Hilmersson and Jansson, 2012). However, a few studies highlight a number of disadvantages that might derive from being embedded in networks while expanding abroad. Such linkages could also provide a restricted and limited horizon in terms of opportunity recognition in foreign markets, thus leading to suboptimal international paths (Ellis, 2011).

While the role of networks in SMEs' internationalisation processes is widely recognized, a few recent studies explore and assess the role of network-related capabilities that could be detained internally by SMEs, and therefore influence the degree and effectiveness of involvement in network relationships. Torkkeli et al. (2012) find that network competence, conceived as an internal organisational capability, positively influences SMEs' propensity to internationalise. With the aim to examine a connection between networking behaviours, resource availability and internationalization, Tang (2011) undertakes a study of 210 Chinese SMEs in Beijing and Hong Kong. He reports that "the ability to plan and conduct networking strategically with key partners is beneficial to enabling rapid internationalization" (Tang, 2011, p. 387). Other contributions explore in more detail the nature and attributes of networking skills and practices, often linked to the entrepreneur (Sullivan and Weerawardena, 2006), which could 
have an active or passive dimension depending on which actor takes the lead in pursuing foreign market initiatives (Ojala, 2009).

A number of studies focus on specific network actors. The role of customer is highlighted in a number of contributions. Customer networks play a significant role in accelerating the internationalisation process (Belso-Martinez, 2006a), pushing SMEs to actively search for new foreign clients (Bradley et al., 2006). Analysing a case of an Italian SME, Vissak and Francioni (2013) discover that the decision to enter into foreign markets is often made in response to the participation in networking events, such as international trade fairs. Rodriguez (2007) highlights that having a network of overseas customers increases credibility not only internationally but at the domestic level.

A few recent studies highlight the role of brokers, intermediaries, consultants and institutions in supporting SMEs' internationalisation processes. These actors provide complementary assets, such as knowledge and network access, which SMEs do not control in the light of their size and limited resources (Ojala, 2009). According to Hessel and Terjesen (2010, p. 204) "an emerging strand of research explores how new and small firms pursue an indirect path to internationalisation using local and foreign intermediaries to sell their goods and services across national borders". Studies in the management literature have examined the relationship quality between exporter and intermediary. Kuhlmeier and Knight (2010) focus on four dimensions: communication, cooperation, trust and commitment. Their findings show that superior relationship quality will lead to enhanced intermediary performance. Madsen et al. (2012) reveal that in 227 small- and medium-sized Norwegian exporting firms cooperating with intermediaries in foreign markets, delegation of decision rights is relatively modest.

\section{Discussion of results}

The review of the recent contributions on drivers of SMEs' exporting activities shows that this topic has received significant attention in the last decade. In this section we assess the main findings, as summarised in Table II, highlighting the new and emerging topics in the literature, thus paving the way to the next section, where possible future research directions will be discussed. 
With regard to internal drivers, recent studies have been focused on factors related to HR, R\&D and marketing, while less attention has been placed on two other factors previously discussed by Leonidou et al., (2007), such as financial and production-related stimuli.

Recent research on HR as a driver for SMEs' exporting shows a wide and rich variety of perspectives. The main focus is on the characteristics of entrepreneurs/managers: competences, education, personality, nationality, age, gender. This attention demonstrates the interest towards HR-related drivers able to explain changes in SMEs' attitude towards expansion in foreign markets. This evolution mirrors the growing focus on the role of HR in SMEs (Pajo et al., 2010) and on the cognitive dimension of the entrepreneurial/managerial team in SMEs (Grégoire et al., 2011).

Contributions on R\&D and innovation show mixed evidence of the impact of proprietary knowledge and product innovation on exporting. Instead, a few studies have highlighted the positive relationship between productivity and export performance, thus suggesting that process innovation in the organisation of production inputs might lead to better results in foreign markets.

With regard to the marketing function, recent studies place emphasis on ICT resources as drivers of market penetration and customer interaction. This new focus is in line with the growing literature on ICTs adoption in SMEs (Barba-Sanchez et al., 2007). On the contrary, less attention is paid on SMEs' ability to collect foreign market information, which represents a key aspect in their expansion in foreign markets (Leonidou, 2004). Another underinvestigated theme is the organization of sales activities. Recent contributions tend to develop analyses of generic exporting activities, and do not examine whether innovation and upgrading of sales organization might represent a driver of increased export propensity and intensity.

According to the reviewed studies, also the purchasing function could be a source of drivers for exporting activities. Operating as buyers in foreign markets might help SMEs in gaining experience and developing contacts with prospective customers.

With regard to external drivers, recent contributions have shown a moderate focus on home and host country factors, while more attention has been placed on network-related drivers for SMEs' exporting activities.

Within home country factors the main focus has been on government-based support measures. Surprisingly, limited research has been explicitly conducted on changing internal market conditions during the recent economic crisis, which had a high impact on SMEs' competitiveness (Naidoo, 2010). With regard to host country factors, a number of contributions 
have focused on foreign-market related factors, while there is lack of research on changes in transnational and foreign government regulations and measures.

Various contributions place emphasis on the role of network ties in promoting and helping SMEs expansion in foreign markets and on SMEs' orientation towards developing specific competences to handle such networks. This is in line with the growing attention towards the role of networks in the analysis of SMEs' behaviour and growth (Street and Cameron, 2007). SMEs' expansion in foreign markets is increasingly dependent on ownership and control of products and resources perceived as valuable by foreign firms active in global value/supply chains. The development of relationships with large multinational customers and distributors allows SMEs to gain market and technological knowledge and most importantly access to further networks across national boundaries (Bradley et al., 2006). A number of reviewed studies on SMEs emphasize the role of social ties developed by the entrepreneurial/managerial team for the international expansion of SMEs. Instead, limited research has been conducted on the role played by specific network actors, beside customers and distributors.

Therefore, this review of recent contributions highlights, on the one hand, the need to update knowledge on the role of recognized and well-established export drivers such as production, financial, government-related stimuli. On the other hand, the analysis of recent literature underlines the opportunity to integrate Leonidou's framework on export stimuli in four ways. First, the category "special managerial interest/urge" could be further specified, by taking into account the personality/subjective and socio-demographic features of entrepreneurs/managers in charge of exporting activities. Secondly, the marketing function as a source of possible drivers could be enriched by the inclusion of ICT and web technologies as factors facilitating the expansion in foreign markets. Thirdly, this review highlights purchasing as a distinct function which could represent a valuable source of stimuli for SMEs' exporting effort. Finally, specific actors such as intermediaries and customers could be grouped within a single category of drivers qualified as "network". This would allow to emphasize the role of networks in supporting SMEs' presence in foreign markets and to gain a more exhaustive and integrated picture of connections with relevant actors.

According to these results, one emerging perspective on drivers could be highlighted: exporting in SMEs is increasingly the outcome of the combination of two complementary and interacting "driving" dimensions: the internal and the external network. This view is in line with the evolution of related streams of research within the international business discipline: the internationalization process literature (Johanson and Vahlne, 2009) and the contributions on the 
organisational configuration of multinational firms (Ghoshal and Bartlett, 1990; Zanfei, 2000; Castellani and Zanfei, 2006; Meyer et al., 2011). On the one hand, recent studies place emphasis on the role of networks as main drivers for timing, breadth and depth of expansion of firms in foreign markets. Notably Johanson and Valhne (2009) make explicit the effect of insidership/outsidership in networks on the ability of firms in penetrating foreign markets. On the other hand, contributions on the organisational configuration of multinational firms highlight the role of internal units as the Headquarter, subsidiaries and specialized units such as international purchasing offices, $R \& D$ units, and sales units. The behaviour of the multinational firms is thus shaped by the interaction and communication flows among the internal units.

Therefore exporting in SMEs could be conceived as shaped by the combined effect of internal and external networks. SMEs have been traditionally viewed as "unitary" actors, where the entrepreneur is the leading figure - in terms of resources, knowledge and mindset - within the organization. Instead, changes in exporting behaviour could be better understood if SMEs were analysed as articulated organizations - even if based on simple configurations - where the entrepreneur takes decisions while interacting with a variety of individual actors - family members, export managers, technical staff - and of internal organisational units, such as the export department, the production function and the R\&D/design units. Some units dealing with international sales could be located in foreign locations, as SMEs start to set up a stable presence in other strategic markets. Each of these individual and organisational actors detain resources, knowledge and skills that could contribute to the upgrading of behaviour by SMES in exporting activities. Meanwhile, SMEs can now involve a wider range of external actors, comprising suppliers, customers, business and institutional intermediaries, consultants. Each of these actors might represent a relevant source of export stimuli in the light of their own resources, knowledge and skills related to foreign markets.

\section{Agenda for future research and policy-making implications}

Even though the topic of SMEs' export and expansion in foreign markets has been widely researched, we argue that further research is needed on both internal and external drivers, taking into consideration the internal/external network dimensions, as proposed above. In Table III we summarise these directions for further research. 
With regard to internal drivers, the analysis of HR related factors could be further pursued analysing in more detail and depth the distinct role of internal actors - entrepreneur, family members, senior and young export managers - both as individuals and as a team in charge of exporting activities. SMEs' upgrading processes are often driven by the introduction of skilled and qualified personnel, which then take part in the export decision-making process. Notably, it could be interesting to explore the involvement of young graduates (Pittaway and Thedham, 2005) with knowledge of foreign markets and languages. A further area of research - neglected thus far - could focus on specific organisational measures concerning HR management and development (Kotey, Slade, 2005), such as HR selection processes, training programs, financial and non-financial incentives.

As concerns the role of R\&D and innovation, future research could, on the one hand, devote more attention on whether design-oriented innovations, which may be able to exploit market niches, have positive impact on exporting. On the other hand, future research could explore whether SMEs where $\mathrm{R} \& \mathrm{D}$ and new product development approach are more formalized and structured (e.g. specialized staff/units, project management skills and resources) show higher performance in exporting activities (Ledwith et al., 2006).

Also, further efforts could be devoted to examine the role of ICT and web technologies in stimulating export activities. Various studies highlight the adoption by SMEs of innovative platforms such as social media (Durkin et al., 2013), having a significant impact on the planning and implementation of sales activities (Andzulis et al., 2012). Following this line of research also more focussed studies on the marketing function within export activities should be encouraged. Some recent contributions reviewed in this paper examine export behaviour by SMEs within generic market strategies, but do not explore in detail whether in the recent period changes in the organization of sales force and sales activities have a positive impact on selling in foreign markets.

Moreover, further research on production-related stimuli could be conducted. The upgrading of production and service activities - implementing quality control systems and leanbased approaches - could provide business opportunities with large foreign customers and distributors, which are increasingly searching for valuable suppliers able to guarantee high product and operational performances on a global scale (Johnsen and Ford, 2006).

As outlined above, this review highlights purchasing as a source of stimuli for exporting. There is a growing field of studies on marketing-purchasing interaction and integration (Sheth et al., 2009). Thus this insight could be developed through research linking sourcing activities by SMEs with international sales and marketing effort. Purchasing effort could stimulate 
exports through collecting relevant foreign market knowledge and suggesting innovative inputs and components, making the final product more competitive in international markets.

With regard to external drivers, this review shows that network-based drivers are playing a growing role in supporting and facilitating SMEs' exporting activities. These results are in line with research on SMEs' involvement in international networks (Coviello and Munro, 1997). Future research could shed more light on two distinct themes. On the one hand, the analysis of specific network configurations could be enhanced. SMEs' suffer from limited size and resources and might be willing to be involved in vertical and horizontal alliances for export development. Such alliances could be based on formal multilateral networks directly - as in the case of export consortia (Musso et al., 2012) - or indirectly - as in the case of R\&D projects (Hottenrott and Lopes-Bento, 2014) - linked to export initiatives. Therefore, further research could help in understanding whether and how SMEs participate towards these frameworks, and what kind of export-related benefits they might gain. On the other hand, the nature and behaviour of specific network actors should be examined in more depth in the light of the changing market and institutional scenarios. Organizations such as trade/business associations (Bennett and Ramsden, 2007) and government agencies could currently play different roles in comparison with the past, in the light of the shrinking of available resources. Moreover, new actors - such as consultancies and knowledge intermediaries (Bennett and Smith, 2004) - could provide support and stimulus for SMEs' export activities. A more in-depth analysis of these relational configurations and patterns might help in gaining a more complete understanding of current opportunities and prospects for SMEs' export orientation. It could be argued that access to resources detained by network partners depends on SMEs' ability to manage these key relationships, as various recent contributions emphasize (Torkkeli et al., 2012; Ngugi and Johnsen, 2010). Thus, further research is needed to gain a better understanding of organisational knowledge and mechanisms developed by SMEs while dealing with export-related business and institutional networks.

Finally, it is worth highlighting some implications of our study for policy-making. Our results suggest that governments could support SMEs' export orientation adopting measures able to strengthen the two complementary areas which have been highlighted in this paper: the internal and the external network. On the one hand policies could facilitate the involvement in SMEs of skilled senior and junior export staff, with high proficiency in foreign languages and a global mind-set. Moreover, such measures could support the setting up projects aimed at innovating and upgrading all functions (production, $R \& D$, sales) related to exporting activities. On the other hand, government policies could encourage vertical and horizontal export 
cooperation among SMEs through the provision of financial and technical assistance to organized networks of SMEs, which demonstrate to be able to share objectives, strategies and resources in their expansion in foreign markets.

\section{References}

Acedo, F. and Galán, J. (2011), "Export stimuli revisited: The influence of the characteristics of managerial decision makers on international behaviour", International Small Business Journal, Vol. 29 No. 6, pp. 648-670.

Andzulis, J., Panagopoulos, G.N. and Rapp, A. (2012), “A Review of Social Media and Implications for the Sales Process", Journal of Personal Selling \& Sales Management, Vol. 32 No 3, pp. 305-316.

Badinger, H. and Url, T. (2013), "Export Credit Guarantees and Export Performance: Evidence from Austrian Firm-level Data", World Economy, Vol. 36, pp. 1115-1130.

Barba-Sanchez, V., Martinez-Ruiz, M. and Jimenez-Zarco, A.I. (2007), "Drivers, benefits and challenges of ICT adoption by small and medium sized enterprises (SMEs): a literature review", Problems and Perspectives in Management, Vol. 5 No 1, pp. 103-114.

Bell, J. (2010), "'New wave' global firms: Web 2.0 and SME internationalisation", Journal of Marketing Management, Vol. 26 No. 3-4, pp. 213-229.

Belso-Martínez, J. A. (2006a), "Why are some Spanish manufacturing firms internationalizing rapidly? The role of business and institutional international networks ", Entrepreneurship \& Regional Development, Vol. 18 No. 3, pp. 207-226.

Belso-Martínez, J. A. (2006b), "Do industrial districts influence export performance and export intensity? Evidence for Spanish SMEs' internationalization process", European Planning Studies, Vol. 14 No. 6, pp. 791-810.

Bennett, R. J. and Ramsden, M. (2007), “The Contribution of Business Associations to SMEs”, International Small Business Journal, Vol. 25 No.1, pp. 49-76.

Bennet, R. J. and Smith, C. (2004), "The Selection and Control of Management Consultants by Small Business Clients”, International Small Business Journal, Vol. 22, pp. 435-462.

Bonner, K. and McGuinness, S. (2007), "Assessing the Impact of Marketing Assistance on the Export Performance of Northern Ireland SMEs", International Review of Applied Economics, Vol. 21 No. 3, pp. 361-379. 
Bradley, F., Meyer, R. and Gao, Y. (2006), "Use of supplier-customer relationships by SMEs to enter foreign markets", Industrial Marketing Management, Vol. 35 No. 6, pp. 652665.

Cardoza, G., Fornes, G., Li, P., Xu, N. and Xu, S. (2015), "China goes global: public policies' influence on small- and medium-sized enterprises' international expansion", Asia Pacific Business Review, Vol. 21 No. 2, pp. 188-210.

Cassiman, B., Golovko, E. and Martinez-Ros, E. (2010), "Innovation, Exports and Productivity", International Journal of Industrial Organization, Vol. 28, pp. 372-376.

Cassiman, B. and Golovko, E. (2011), "Innovation and Internationalization through Exports", Journal of International Business Studies, Vol. 42, pp. 56-75.

Castellani, D. and Zanfei, A. (2006), Multinational Firms, Innovation and Productivity, Edward Elgar, Cheltenham.

Cerrato, D. and Piva, M. (2012), "The internationalization of small and medium-sized enterprises: the effect of family management, human capital and foreign ownership", Journal of Management Government, Vol. 16, pp. 617-644.

Chen, H.-L., Hsu, W.-T. and Chang, C.-Y. (2014), "Family Ownership, Institutional Ownership, and Internationalization of SMEs", Journal of Small Business Management, Vol. 52 No. 4, pp. 771-789.

Ciravegna, L., Lopez, L. and Kundu, S. (2014), "Country of origin and network effects on internationalization: A comparative study of SMEs from an emerging and developed economy", Journal of Business Research, Vol. 67, pp. 916-923.

Coudounarisa, D. N. (2011), "Influences of Managerial Drivers on Export Sales Units' Performance of Small and Medium-Size Enterprises", Journal of Global Marketing, Vol. 24 No. 4, pp. 324-344.

Coviello, N. and Munro, H. (1997), "Network Relationships and the Internationalisation Process of Small Software Firms", International Business Review, Vol. 6 No. 4, pp. 361386.

Crick, D. (2007), "UK SMEs' motives for internationalizing: Differences between firms employing particular overseas market servicing strategies", Journal of International Entrepreneurship, Vol. 5 No. 1-2, pp. 11-23.

D’Angelo, A. (2012), "Innovation and export performance: a study of Italian high-tech SMEs", Journal of Management Government, Vol. 16, pp. 393-423.

Damijan, J. P., Kostevc, C. and Polanec, S. (2010), "From Innovation to Exporting or Vice Versa?", The World Economy, Vol. 33, pp. 374-398. 
Durkin, M., McGowan, P. and McKeown, N. (2013), “Exploring social media adoption in small to medium-sized enterprises in Ireland", Journal of Small Business and Enterprise Development, Vol. 20 No 4, pp. 716-734.

Durmuşoğlu, S. S., Apfelthaler, G., Nayir, D. Z., Alvarez, R. and Mughan, T. (2012), "The effect of government-designed export promotion service use on small- and mediumsized enterprise goal achievement: A multidimensional view of export performance", Industrial Marketing Management, Vol. 41, pp. 680-692.

Eliasson, K., Hansson, P. and Lindvert, M. (2012), "Do firms learn by exporting or learn to export? Evidence from small and medium-sized enterprises", Small Business Economics, Vol. 39, pp. 453-472.

Ellis, P. (2011), "Social ties and international entrepreneurship: Opportunities and constraints affecting firm internationalization", Journal of International Business Studies, Vol. 42, pp. 99-127.

European Commission (2014), Helping Firms Grow, European Competitiveness Report 2014.

Falk, M. and Hagsten, E. (2015), "Export Behaviour of Micro Firms in the Swedish Computer and Business Service Industries", Economics, Vol. 9, October, pp. 1-24.

Felício, J. A., Caldeirinha, V. R. and Rodrigues, R. (2012), "Global mindset and the internationalization of small firms: The importance of the characteristics of entrepreneurs", International Entrepreneurship and Management Journal, Vol. 8 No. 4, pp. 467-485.

Felício, J. A., Caldeirinha, V. R., Rodrigues, R. and Kyvik, O. (2013), "Cross-cultural analysis of the global mindset and the internationalization behavior of small firms", International Entrepreneurship and Management Journal, Vol. 9 No. 4, pp. 641-654.

Felício, J. A., Caldeirinha, V. R. and Ribeiro-Navarrete, B. (2015), "Corporate and individual global mind-set and internationalization of European SMEs", Journal of Business Research, Vol. 68, pp. 797-802.

Fernández, Z. and Nieto, M. J. (2006), "Impact of ownership on the international involvement of SMEs", Journal of International Business Studies, Vol. 37, pp. 340-351.

Fernandez-Ortiz, R. and Lombardo, G. F. (2009), "Influence of the capacities of top management on the internationalization of SMEs", Entrepreneurship \& Regional Development, Vol. 21 No. 2, pp. 131-154.

Frishammar, J. and Andersson, S. (2009), "The overestimated role of strategic orientations for international performance in smaller firms", Journal of International Entrepreneurship, Vol. 7, pp. 57-77. 
Garvey, D. and Brennan, L. (2006), "The Internationalisation of Indigenous Irish Software Technology Companies: An Exploratory Study", Irish Journal of Management, Vol. 26 No. 2, pp. 81-108.

Ghoshal, S., \& Bartlett, C. A. (1990), "The multinational corporation as an interorganizational network", Academy of Management Review, Vol.15, pp. 603-625.

Gorman, G., Hanlon, D. and King, W. (1997), "Some research perspectives on entrepreneurship education, enterprise education and education for small business management: a tenyear literature review", International Small Business Journal, Vol. 15, pp. 56-77.

Grégoire, D. A., Corbett, A. C. and McMullen, J. S. (2011), "The Cognitive Perspective in Entrepreneurship: An Agenda for Future Research", Journal of Management Studies, Vol. 48, pp. 1443-1477.

Hilmersson, M. and Jansson, H. (2012), "International network extension processes to institutionally different markets: Entry nodes and processes of exporting SMEs", International Business Review Vol. 21, pp. 682-693.

Hessels, J. and Terjesen, S. (2010), "Resource dependency and institutional theory perspectives on direct and indirect export choices", Small Business Economics, Vol. 34 No. 2, pp. 203-220.

Holmlund, M., Kock, S. and Vanyushyn, V. (2007), "Small and Medium-sized Enterprises' Internationalization and the Influence of Importing and Exporting", International Small Business Journal, Vol. 25 No. 5, pp. 459-477.

Hottenrott, H. and Lopes-Bento, C. (2014), “(International) R\&D collaboration and SMEs: The effectiveness of targeted public R\&D support schemes", Research Policy, Vol. 43 No. 6, pp. 1055-1066.

Hsu, W.-T., Chen, H.-L. and Cheng, C.-Y. (2013), "Internationalization and firm performance of SMEs: The moderating effects of CEO attributes", Journal of World Business, Vol. 48, pp. 1-12.

Janda, K., Michalikova, E. and Skuhrovec, J. (2013), "Credit Support for Export: Robust Evidence from the Czech Republic", The World Economy, Vol. 36, pp. 1588-1610.

Johanson, J. and Vahlne, E. (2009), "The Uppsala internationalization process model revisited: From liability of foreigness to liability of outsidership", Journal of International Business Studies, Vol. 40 No. 9, pp. 1411-1431.

Johnsen, R, and Ford, D. (2006), "Interaction capability development of smaller suppliers in relationships with larger customers", Industrial Marketing Management, Vol. 35, pp. 1002-1015. 
Jones, M. V. and Coviello, N. E. (2005), "Internationalisation: conceptualising an entrepreneurial process of behaviour in time", Journal of International Business Studies, Vol. 36, pp. 284-303.

Karadeniz, E. E. and Göçer, K. (2007), "Internationalization of small firms. A case study of Turkish small- and medium-sized enterprises", European Business Review, Vol. 19 No. 5, pp. 387-403.

Kaur, S. and Singh Sandhu, M. (2013), "Internationalisation of born global firms: Evidence from Malaysia", Journal of the Asia Pacific Economy, Vol. 19 No. 1, pp. 101-136.

Kontinen, T. and Ojala, A. (2010), "The internationalization of family businesses: A review of extant research", Journal of Family Business Strategy, Vol. 1, pp. 97-107.

Kontinen, T. and Ojala, A. (2011), "Network ties in the international opportunity recognition of family SMEs", International Business Review, Vol. 20, pp. 440-453.

Korsakienè, R. and Tvaronavičienè, M. (2012), "The internationalization of SMEs: an integrative approach", Journal of Business Economics and Management, Vol. 13 No. 2, pp. 294-307.

Kotey, B. and Slade, P. (2005), "Formal Human Resource Management Practices in Small Growing Firms”, Journal of Small Business Management, Vol. 43 No. 1, pp. 16-40.

Kuhlmeier, D. B. and Knight, G. (2010), "The Critical Role of Relationship Quality in Smalland Medium-Sized Enterprise Internationalization", Journal of Global Marketing, Vol. 23 No. 1, pp. 16-32.

Kyvik, O., Saris, W., Bonet, E. and Felício, J. A. (2013), "The internationalization of small firms: The relationship between the global mindset and firms' internationalization behavior", Journal of International Entrepreneurship, Vol. 11, pp. 172-195.

Lamb, P., Sandberg, J. and Liesch, P. W. (2011), "Small firm internationalisation unveiled through phenomenograph", Journal of International Business Studies, Vol. 42, pp. 672693.

Laufs, K. and Schwens, C. (2014), "Foreign market entry mode choice of small and mediumsized enterprises: A systematic review and future research agenda", International Business Review, Vol. 23, pp. 1109-1126.

Ledwith, A., Richardson, I. and Sheahan, A. (2006), "Small firm - large firm experiences in managing NPD projects", Journal of Small Business and Enterprise Development, Vol. 13 No. 3, pp. 425-440.

Leonidou, L. C. (2004), "An Analysis of the Barriers Hindering Small Business Export Development", Journal of Small Business Management, Vol. 42 No. 3, pp. 279-302. 
Leonidou, L. C., Katsikeas, C. S., Palihawadana, D. and Spyropoulou, S. (2007), "An analytical review of the factors stimulating smaller firms to export: Implications for policymakers", International Marketing Review, Vol. 24 No. 6, pp. 735-770.

Loane, S. (2006), "The role of the internet in the internationalisation of small and medium sized companies", Journal of International Entrepreneurship, Vol. 3, pp. 263-277.

Love, J. H. and Roper, S. (2015), "SME innovation, exporting and growth: A review of existing evidence", International Small Business Journal, Vol. 33 No. 1, pp. 28-48.

Madsen, T. K., Moen, Ø. and Hammervold, R. (2012), "The role of independent intermediaries: The case of small and medium-sized exporters", International Business Review, Vol. 21 No 4, pp. 535-546.

Mesquita, L. F. and Lazzarini, S. G. (2008), "Horizontal and Vertical Relationships in Developing Economies: Implications for SMEs' Access to Global Markets", Academy af Management Journal, Vol. 51 No. 2, pp. 359-380.

Meyer, K. E., Mudambi, R., and Narula, R. (2011), "Multinational enterprises and local contexts: the opportunities and challenges of multiple embeddedness", Journal of Management Studies, Vol. 48 No.2, pp. 235-252.

Miocevic, D. and Crnjak-Karanovic, B. (2011), "Cognitive and Information-Based Capabilities in the Internationalization of Small and Medium-Sized Enterprises: The Case of Croatian Exporters", Journal of Small Business Management, Vol. 49 No. 4, pp. 537557.

Mostafa, R. H. A., Wheeler, C. and Jones, M. V. (2006), "Entrepreneurial orientation, commitment to the Internet and export performance in small and medium sized exporting firms", Journal of International Entrepreneurship, Vol. 3, pp. 291-302.

Musso, F., Francioni, B. and Pagano, A. (2012), "The role of country of origin in supporting export consortia in emerging markets", in Bertoli, G. and Resciniti, R. (Eds.), International Marketing and the Country-of-Origin Effect. Edward Elgar, Cheltenham.

Musteen, M., Francis, J. and Datta, D. K. (2010), "The influence of international networks on internationalization speed and performance: A study of Czech SMEs", Journal of World Business, Vol. 45, pp. 197-205.

Musteen, M., Datta, D. K. and Butts, M. M. (2014), "Do International Networks and Foreign Market Knowledge Facilitate SME Internationalization? Evidence From the Czech Republic", Entrepreneurship Theory and Practice, Vol. 38, pp. 749-774. 
Naidoo, V. (2010), "Firm survival through a crisis: The influence of market orientation, marketing innovation and business strategy", Industrial Marketing Management, Vol. 39 No. 8, pp. 1311-1320.

Ngugi, I.K. and Johnsen, R.E. (2010), "Relational capabilities for value co-creation and innovation in SMEs", Journal of Small Business and Enterprise Development, Vol. 17, pp. 260-278.

Nowinski, W. and Rialp, A. (2013), "Drivers and strategies of international new ventures from a Central European transition economy", Journal for East European Management Studies, Vol. 2, pp. 191-231.

Ojala, A. (2009), "Internationalization of knowledge-intensive SMEs: The role of network relationships in the entry to a psychically distant market", International Business Review, Vol. 18, pp. 50-59.

Ojala, A. and Isomäki, H. (2011), "Entrepreneurship and small businesses in Russia: a review of empirical research", Journal of Small Business and Enterprise Development, Vol. 18 No. 1, pp. 97 - 119.

Omri, W. and Becuwe, A. (2014), "Managerial characteristics and entrepreneurial internationalization: A study of Tunisian SMEs", Journal of International Entrepreneurship, Vol. 12, pp. 8-42.

Onkelinx, J., Manolova, T. S. and Edelman, L. F. (2015), "Human capital and SME internationalization: Empirical evidence from Belgium", International Small Business Journal, pp. 1-20.

Orser, B., Spence, M., Riding, A. and Carrington, C. A. (2010), "Gender and Export Propensity", Entrepreneurship Theory and Practice, Vol. 34, pp. 933-957.

Ottaviano, G. and Volpe Martincus, C. (2011), "SMEs in Argentina: who are the exporters?", Small Business Economics, Vol. 37 No. 4, pp. 341-361.

Pajo, K., Coetzer, A. and Guenole, N. (2010), "Formal development opportunities and withdrawal behaviours by employees in small and medium-sized enterprises", Journal of Small Business Management, Vol. 48, pp. 281-301.

Pangarkar, N. (2008), "Internationalization and performance of small and medium-sized enterprises", Journal of World Business, Vol. 43, pp. 475-485.

Pangarkar, N. and Hussain, S. (2013), "The Internationalization of Singaporean Small and Medium-Size Enterprises", International Studies of Management \& Organization Vol. 43 No. 2, pp. 30-55. 
Pittaway, L. and Thedham, J. (2005), "Mind the Gap. Graduate Recruitment in Small Businesses”, International Small Business Journal, Vol. 23, pp. 403-426.

Ramos, E., Acedo, F. J. and Gonzalez, M. R. (2011), "Internationalisation speed and technological patterns: A panel data study on Spanish SMEs", Technovation, Vol. 31, pp. 560-572.

Rodriguez, J. (2007), "The Internationalisation of the Small and Medium-sized Firm", Prometheus, Vol. 25 No. 3, pp. 305-317.

Rundh, B. (2007), "International marketing behaviour amongst exporting firms", European Journal of Marketing, Vol. 41 No. 1/2, pp. 181-198.

Sciascia, S., Mazzola, P., Astrachan, J. H. and Pieper, T. M. (2012), "The Role of Family Ownership in International Entrepreneurship: Exploring Nonlinear Effects", Small Business Economics, Vol. 38 No. 1, pp. 15-31.

Serra, F., Pointon, J. and Abdou, H. (2012), "Factors influencing the propensity to export: A study of UK and Portuguese textile firms", International Business Review, Vol. 21, pp. 210-224.

Sheth, J. N., Sharma, A. and Iyer G.R. (2009). "Why integrating purchasing with marketing is both inevitable and beneficial", Industrial Marketing Management, Vol. 38 No. 8, pp. 865-871.

Sinkovics, N., Sinkovics, R. R. and Jean, R.-J. B. (2013), "The internet as an alternative path to internationalization?", International Marketing Review, Vol. 30 No. 2, pp. 130-155.

Sousa, C. M. P. and Bradley, F. (2009), "Effects of Export Assistance and Distributor Support on the Performance of SMEs. The Case of Portuguese Export Ventures", International Small Business Journal, Vol. 27 No. 6, pp. 681-701.

Street, C.T. and Cameron, A.F. (2007), "External Relationships and the Small Business: A Review of Small Business Alliance and Network Research", Journal of Small Business Management, Vol. 45 No 2, pp. 239-266.

Sui, S., Morgan, H. M. and Baum, M. (2015), "Internationalization of immigrant-owned SMEs: The role of language", Journal of World Business, Vol. 50, pp. 804-814.

Sullivan Mort, G. and Weerawardena, J. (2006), "Networking capability and international entrepreneurship. How networks function in Australian born global firms", International Marketing Review, Vol. 23 No. 5, pp. 549-572.

Tang, Y. K. (2011), "The Influence of networking on the internationalization of SMEs: Evidence from internationalized Chinese firms", International Small Business Journal, Vol. 29 No. 4, pp. 374-398. 
Tranfield, D., Denyer, D. and Smart, P. (2003), "Towards a methodology for developing evidence-informed management knowledge by means of systematic review", British Journal of Management, Vol. 14 No. 3, pp. 207-222.

Torkkeli, L., Puumalainen, K., Saarenketo, S. and Kuivalainen, O. (2012), "The effect of network competence and environmental hostility on the internationalization of SMEs", Journal of International Entrepreneurship, Vol. 10, pp. 25-49.

Tracey, J. B. (2014), "A review of human resources management research", International Journal of Contemporary Hospitality Management, Vol. 26, pp. 679-705.

Tseng, K.-M. K. and Johnsen, R. E. (2011), "Internationalisation and the internet in UK manufacturing SMEs", Journal of Small Business and Enterprise Development, Vol. 18 No. 3, pp. 571-593.

Van Beveren, I. and Vandenbussche, H. (2010), "Product and Process Innovation and Firms' Decision to Export", Journal of Economic Policy Reform, Vol. 13, pp. 3-24.

Vissak, T. and Francioni, B. (2013), "Serial nonlinear internationalization in practice: A case study", International Business Review, Vol. 22, pp. 951-962.

Wilkinson, T. J. and Brouthers, L. E. (2006), "Trade Promotion and SME Export Performance", International Business Review, Vol. 15 No. 3, pp. 233-252.

Williams, D. A. (2008), "Export stimulation of micro- and small locally owned firms from emerging environments: New evidence", Journal of International Entrepreneurship, No. 6, pp. 101-122.

Xie, Y. H. and Suh, T. (2014), "Perceived resource deficiency and internationalization of small and medium-sized firms", Journal of International Entrepreneurship, Vol. 12 No. 3, pp. 207-229.

Zanfei, A. (2000), "Transnational firms and the changing organisation of innovative activities", Cambridge Journal of Economics, Vol. 24, pp. 515-542.

Zucchella, A., Palamara, G. and Denicolai, S. (2007), "The drivers of the early internationalization of the firm", Journal of World Business, Vol. 42, pp. 268-280. 